The International Journal of Engineering and Science (IJES)

|| Volume || 6 || Issue || 6 || Pages || PP 62-69 || 2017 ||

ISSN (e): 2319 - 1813 ISSN (p): $2319-1805$

\title{
A Statistical Study on Age Data in Census Andhra Pradesh and Telangana
}

\author{
M. Sripriya, C. Jayalakshmi \\ Dept.of Statistics, Osmania University, Hyderabad-500007
}

\begin{abstract}
-
We regularly come across the news item either in TV or newspapers about death of people in road accidents. It has been observed that in majority of these accidents people who are dyeing belong to male community. This type of news item made us to take up a study on the marital status of people in Telangana and Andhra Pradesh districts. The census data from 1991-2011 is collected on widows and a statistical analysis is made using the statistical tool Shewhart control chart. We have computed widows ratio for all the districts in Telangana and Andhra Pradesh for rural and urban areas separately and made a continuous observation of this feature from 1991-2011. The analysis, comparisons and drawn conclusions are presented in this paper.
\end{abstract}

Keywords: Marital Status, Ratio, Widower, Rural, Urban, Census data.

Date of Submission: 05 June 2017

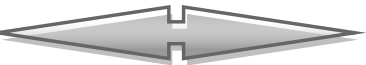

Date of Accepted: 22 June 2017

\section{INTRODUCTION}

In day to day life that in print media and visual media we regularly come across death of people in accidents. We observe that in majority of the cases, the persons who are dyeing are male members. This feature created interest in us to take up a statistical study on the status of females in the associated family. We collected secondary data from the census office of Telangana and Andhra Pradesh states in this respect.

In census 1991-2011, the data pertaining to marital status of different age groups is recorded under the category "Age Data". This data is available district wise for all the districts of Andhra Pradesh and Telangana according to the district boarders existed in 2011. In each district this data is even available for urban and rural areas separately gender wise.

\section{STATISTICAL ANALYSIS:}

In census records, under age data we find number of widows, number of divorcees and people never married for different age groups for both genders separately. We considered in this paper only the widowers case. Under the category of widowers, we find members under female category are almost 10 folds to male category. According to our perception, this difference could be due to the reason that when census data is collected they are not recording the information from married couple whether it is their first marriage or second marriage. We conceive the opinion from the present contemporary world, a second marriage of male widow is encouraged and more easily accepted by people psychologically when compared to a second marriage of female widow. But, a point to be noted in red ink is that lose of spouse only makes a male or female widow. Irrespective of encouragement, acceptance and performance of second marriage the point which should be emphasized is that why "so many deaths of married males in different age groups". We probedinto this point in a detail manner and made a statistical study on it.

\section{Statistical tools used:}

We divided the different age groups given in census data into four categories as $<19,20-30,30-40$ and $>40$. We computed widow's specific ratio as

(Number of female widows in that age group over the number of males of the same age group) multiplied by 1000 .

For these ratios, we constructed Shewhart control chart for all districts under different age groups for census data of 1991, 2001 and 2011. Control charts are constructed separately for Rural and Urban areas.

\section{Method of constructing control chart:}

If $t$ ' is the statistic under study, then Shewhart control chart limits are defined as

Upper control limit $=\mathrm{E}(\mathrm{t})+3 * \operatorname{S.E}(\mathrm{t})$

Lower control limit $=\mathrm{E}(\mathrm{t})-3 *$ S.E $(\mathrm{t})$

Central line $=\mathrm{E}(\mathrm{t})$.

We plot the observed data and the control limits on the same graph which is known as Shewhart control chart. 
Plotting of Central Line and the Control Limits and ratios on the same graph is nothing but Construction of Control Chart. Control charts are plotted on a rectangular co-ordinate axis - ordinate representing the Statistical measure -Widows ratio and abscissa representing the districts. If any district ratio fall above the Upper Control Limit then those districts show very high widows rate. The charts are presented below.

\section{Rural Widows ratio graphs:}
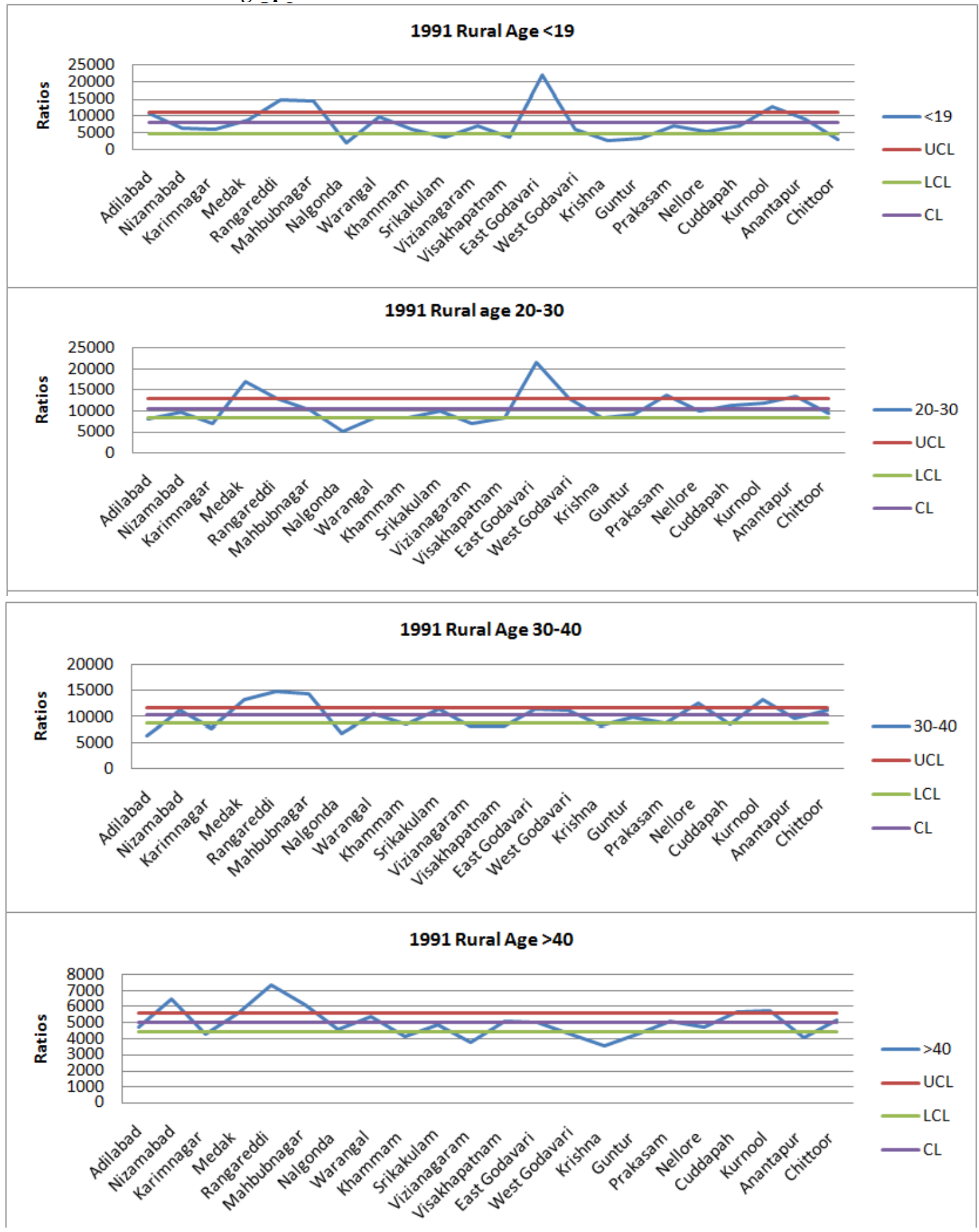
2001 Rural Widows ratio graphs:
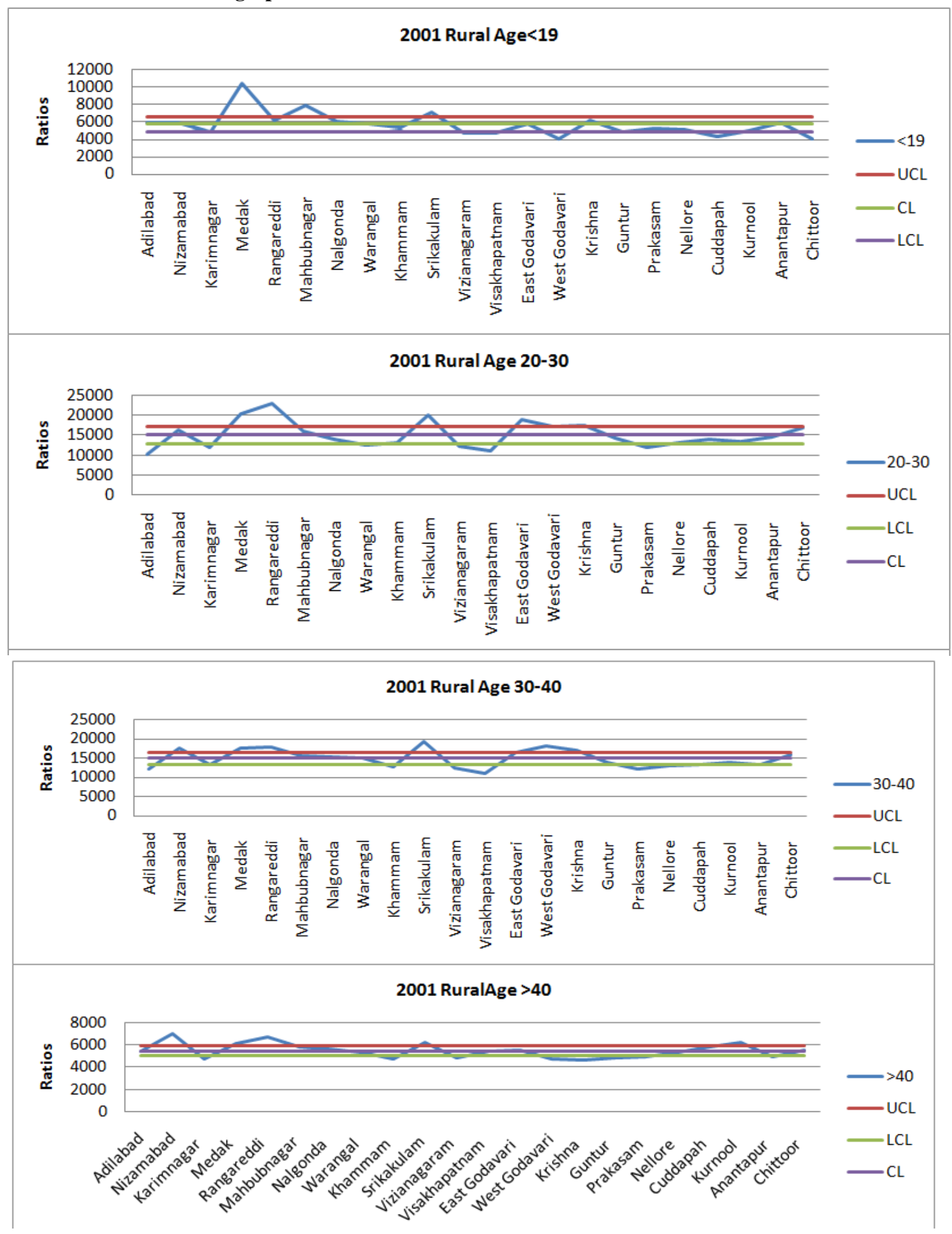
2011 Rural Widows ratio graphs:
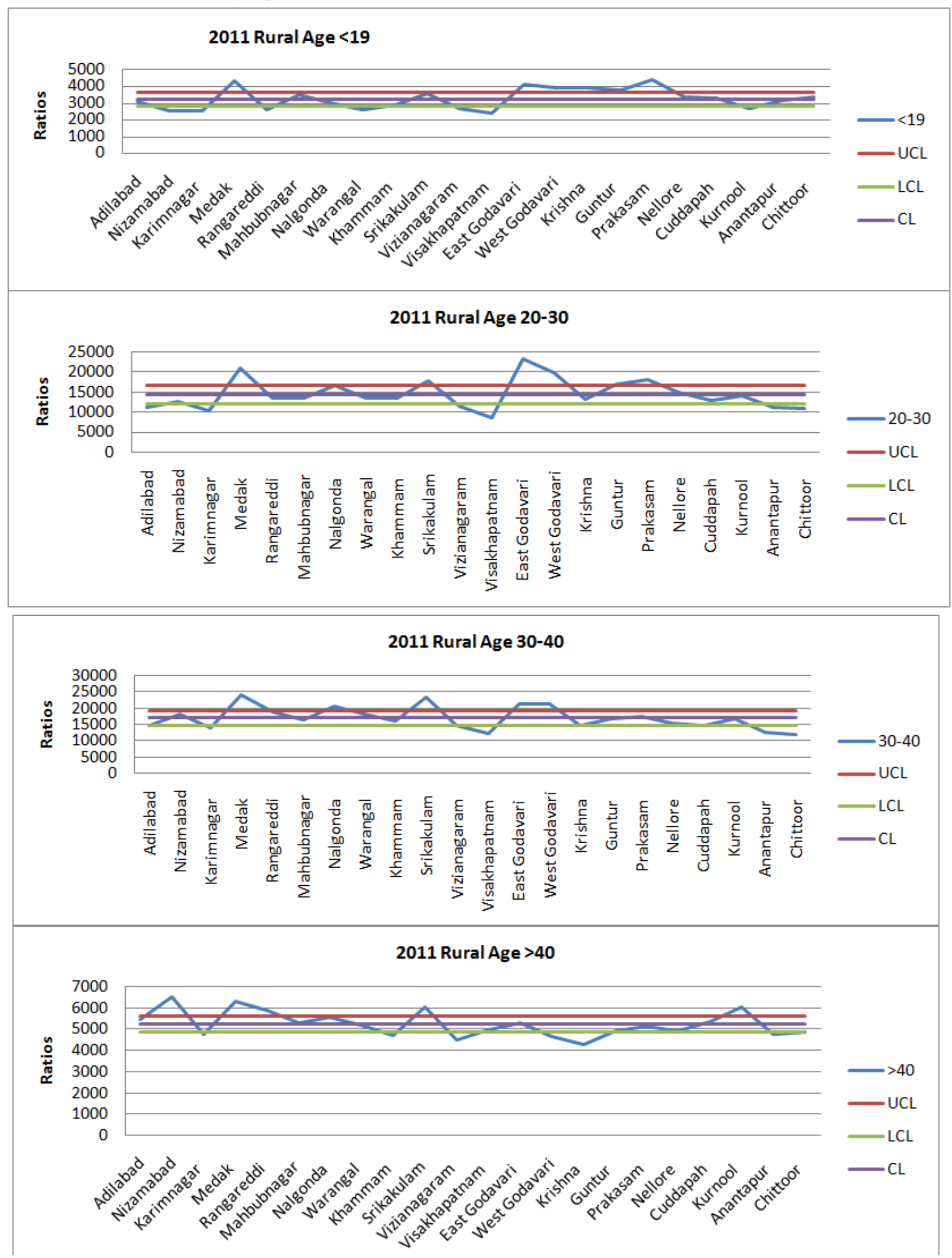
1991 UrbanWidows ratio graphs:
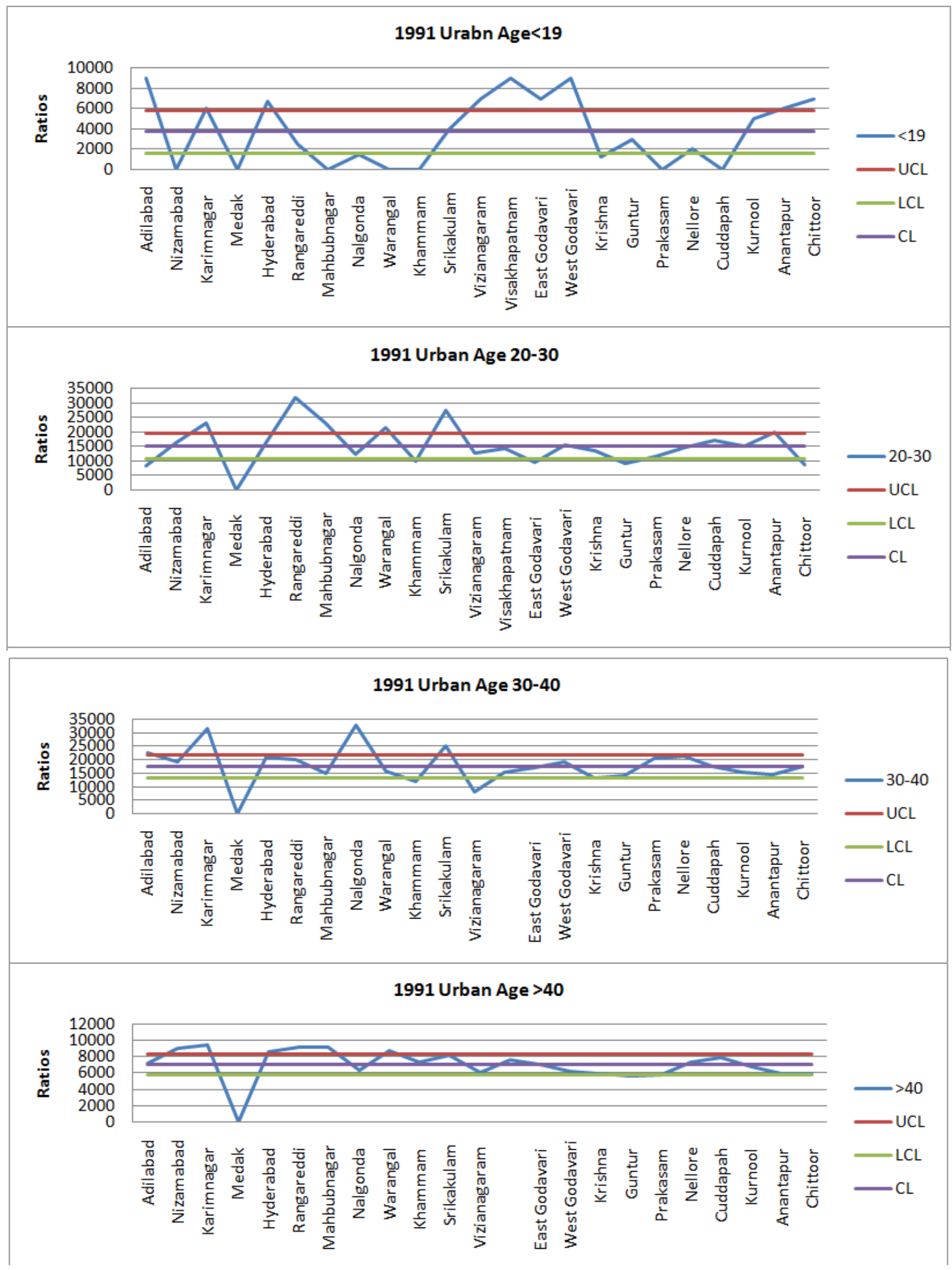
2001 UrbanWidows ratio graphs:
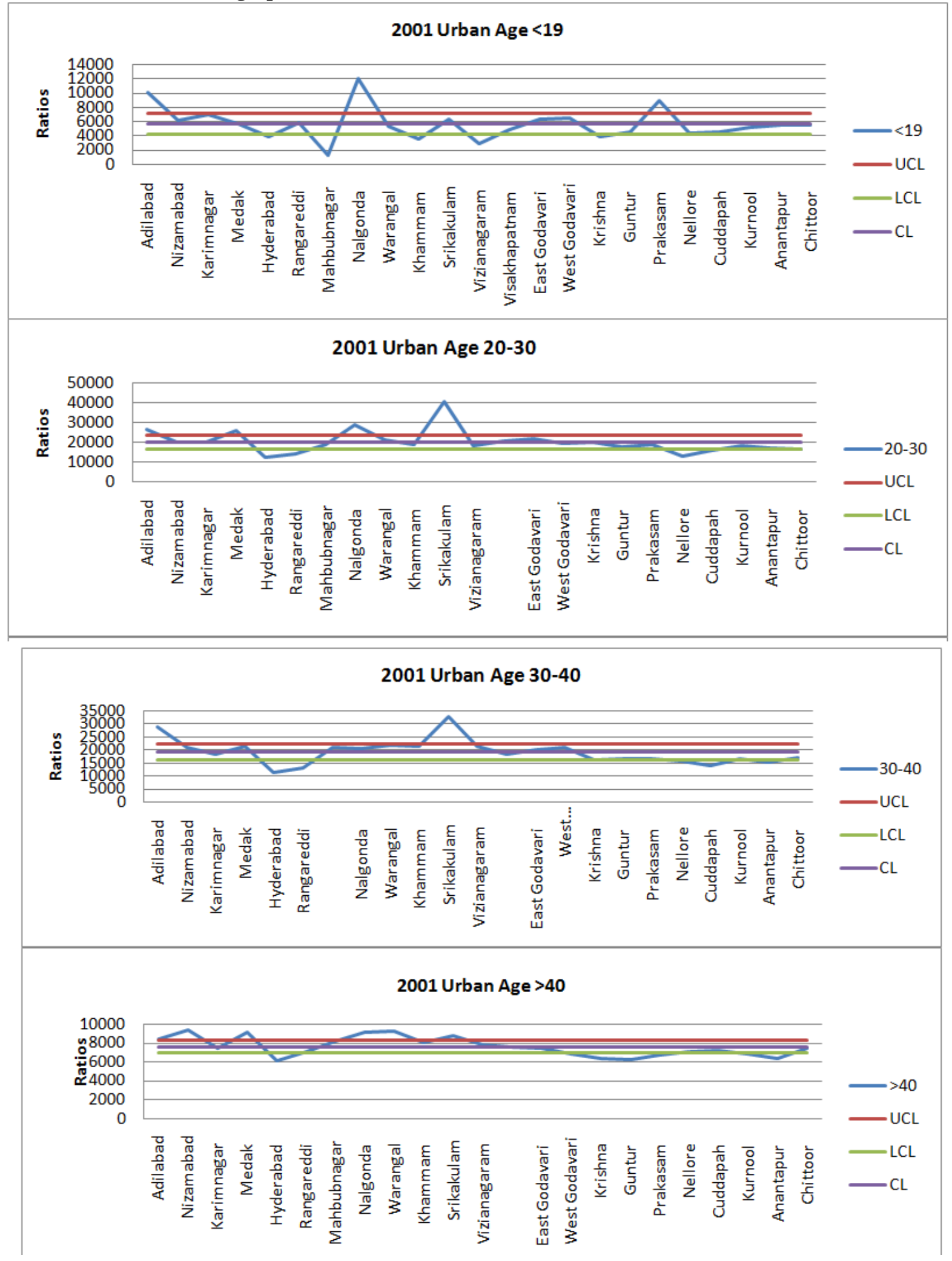
2011 UrbanWidows ratio graphs:
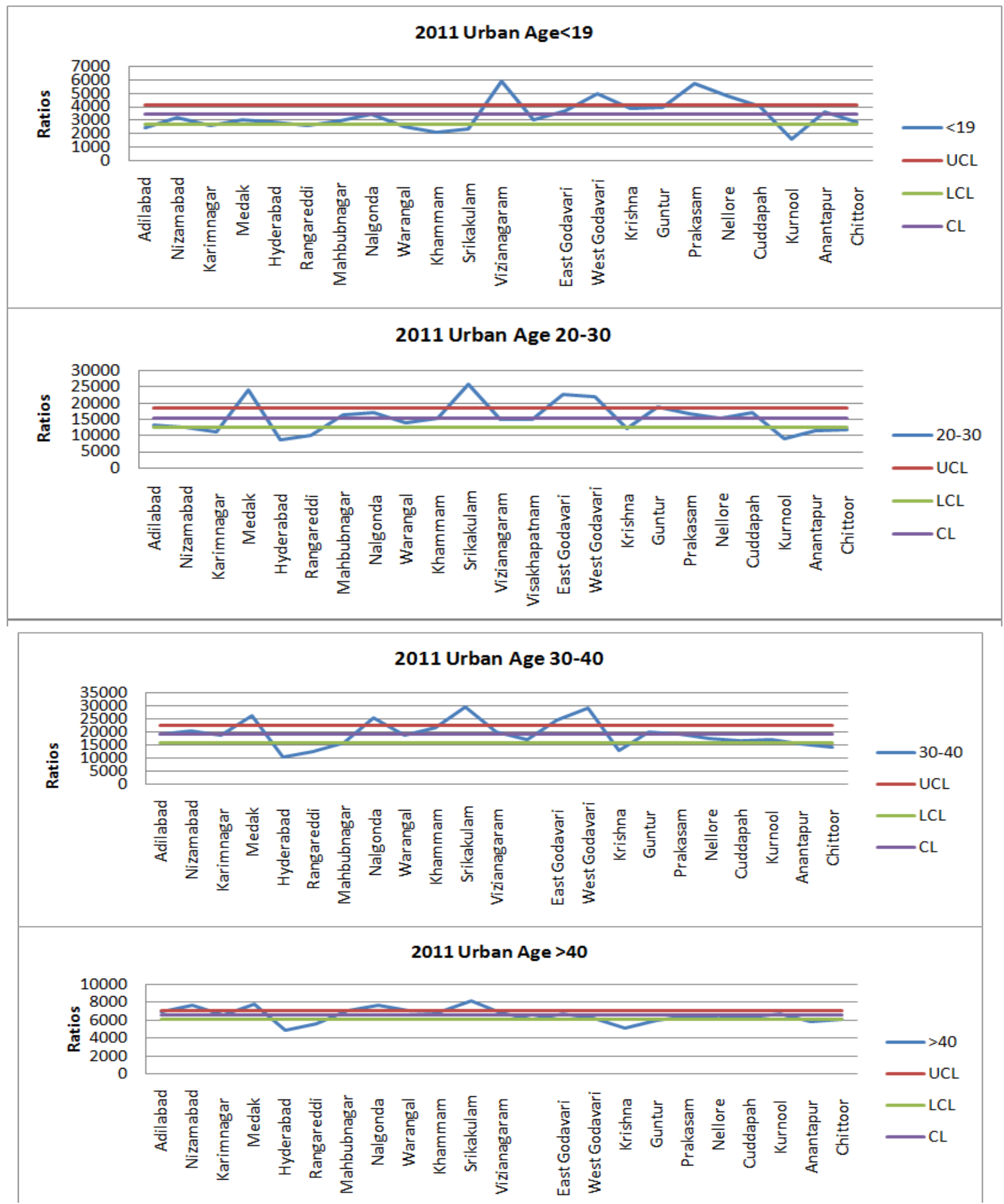

Table 1: Showing the high ratio of widowers in rural areas of different districts in census of 1991, 2001 \& 2011

\begin{tabular}{|c|c|c|c|}
\hline Widows & $\mathbf{1 9 9 1}$ & $\mathbf{2 0 0 1}$ & $\mathbf{2 0 1 1}$ \\
\hline$<19$ & $\begin{array}{c}\text { Rangareddi, Mahboobnangar, East } \\
\text { Godavari, Kurnool. }\end{array}$ & Medak, Mahboobnangar. & $\begin{array}{c}\text { Medak, East Godavari, West Godavari, } \\
\text { Krishna, Guntur, Prakasam. }\end{array}$ \\
\hline $20-30$ & Medak, East Godavari. & Medak, Rangareddi, Srikakulam, East \\
& Godavari. & $\begin{array}{c}\text { Medak, East Godavari, West Godavari, } \\
\text { Prakasam. }\end{array}$ \\
\hline $30-40$ & Medak, Rangareddi, & Srikakulam, West Godavari, Medak, & Medak, Srikakulam, East Godavari, West \\
& Mahboobnangar, Kurnool. & Rangareddi, Nizamabad. & Srikakulam, Nizamabad, Medak, Kurnool. \\
\hline$>40$ & Rangareddi, Nizamabad & Rangareddi, Nizamabad & \\
\hline
\end{tabular}


Table 2: Showing the high widows ratio in urban areas of different districts in different categories of 1991, $2001 \& 2011$ data.

\begin{tabular}{|c|c|c|c|}
\hline Widows & $\mathbf{1 9 9 1}$ & $\mathbf{2 0 0 1}$ & $\mathbf{2 0 1 1}$ \\
\hline$<19$ & $\begin{array}{c}\text { Adilabad,Vizianagaram, } \\
\text { Visakhapatnam, East Godavari, West } \\
\text { Godavari, Chittoor. }\end{array}$ & $\begin{array}{c}\text { Adilabad, Nalgonda, } \\
\text { Prakasam. }\end{array}$ & $\begin{array}{c}\text { Vizianagaram, West Godavari, } \\
\text { Prakasam. }\end{array}$ \\
\hline $20-30$ & Karimnagar, Rangareddi, Srikakulam & Nalgonda, Srikakulam. & $\begin{array}{c}\text { Medak, Srikakulam East } \\
\text { Godavari, West Godavari,. }\end{array}$ \\
\hline $30-40$ & Karimnagar Nalgonda, Srikakulam. & Srikakulam, Adilabad. & $\begin{array}{c}\text { Medak, Nalgonda, Srikakulam, } \\
\text { East Godavari, West Godavari }\end{array}$ \\
\hline$>40$ & $\begin{array}{c}\text { Rangareddi, Nizamabad, Karimnagar, } \\
\text { Mahboobnangar }\end{array}$ & $\begin{array}{c}\text { Nizamabad, Medak, Nalgonda, } \\
\text { Warangal, Srikakulam. }\end{array}$ & $\begin{array}{c}\text { Nizamabad, Medak, Nalgonda, } \\
\text { Srikakulam. }\end{array}$ \\
\hline
\end{tabular}

The following are the observations from the above two tables.

1. In Urban areas of Telangana and Andhra Pradesh, in 1991, more married male deaths below 19 years age to take place in 6 districts which has reduced over a period of 20 years completely in Telangana district, but continued to occur even after 2001 in the districts Vizianagaram, West Godavari and Prakasam of AP.

2. In the age group 20-30, deaths among married males has reduced in Karimnagar and Rangareddi districts but increased in Medak, East Godavari and West Godavari districts over the 20 years period from 1991-2011. It may be particularly noted that in Srikakulam district continuously abnormal married male deaths are taking place.

3. On an average in the remaining two age groups (30-40 and >40) also these deaths have shown increasing tendency from 1991-2011.

4. As far as rural areas are concerned death of married males has decreased in the districts of Telangana except in Medak. Medak has shown consistently abnormal deaths in all the age groups from 1991-2011.

5. On the other hand this type of deaths were initially recorded in less number of AP (1or 2 districts only) in 1991. From 2001 onwards the scenario has shown abnormal levels in the districts East Godavari, West Godavari, Srikakulam, Kurnool, Guntur and Prakasam of Andhra Pradesh.

\section{CONCLUSIONS:}

We reinstate here that a married female becomes widow only when she loses her spouse. In rural areas of some districts of Andhra Pradesh, urban areas of some districts in Telangana and Andhra Pradesh are showing abnormal death record. The reasons could be more road accidents or more high-way accidents or spread of death causing diseases like HIV. Further investigations are to be made to identify exact results for these deaths.

\section{ACKNOWLEDGEMENTS:}

The authors are grateful to the Data Dissemination Section, Directorate of Census Operations, Govt. of Andhra Pradesh \& Telangana, Hyderabad for providing the data.

\section{REFERENCES:}

[1] Douglas C. Montgomery (2008): Introduction to Statistical Quality Control, $6^{\text {th }}$ Edition - , John Wiley \& Sons, Inc. 